\title{
Plastshow 2004 - Teoria e Prática da Transformação de Plásticos
}

A cidade de São Paulo sediou, nos dias 27, 28 e 29 de abril, o PlastShow 2004 - soluções para a indústria de transformação de plásticos. Em sua segunda edição (a primeira foi em 2002 e a próxima será em 2006), o evento reuniu um congresso a que compareceram 400 congressistas, assistindo a mais de 50 palestras técnicas relativas a diversos assuntos importantes para este segmento da indústria, e uma feira de negócios, com mais de cem expositores, entre empresas fornecedoras de equipamentos, materiais, ferramentas, acessórios, software e prestadoras de serviços.

As palestras foram divididas em 12 painéis, formados por seções que abordavam materiais, técnicas, equipamentos e processos, entre outros tópicos, com os temas plásticos de engenharia, especiais e compostos; construção de moldes e matrizes; processo de extrusão; processo de injeção; automação industrial; técnicas e análises de laboratório; gestão de projetos e desenvolvimento de produtos; termoplásticos de uso geral e aditivos; embalagens flexíveis; elastômeros termoplásticos; reciclagem e plásticos biodegradáveis; design, prototipagem e ferramental rápido.

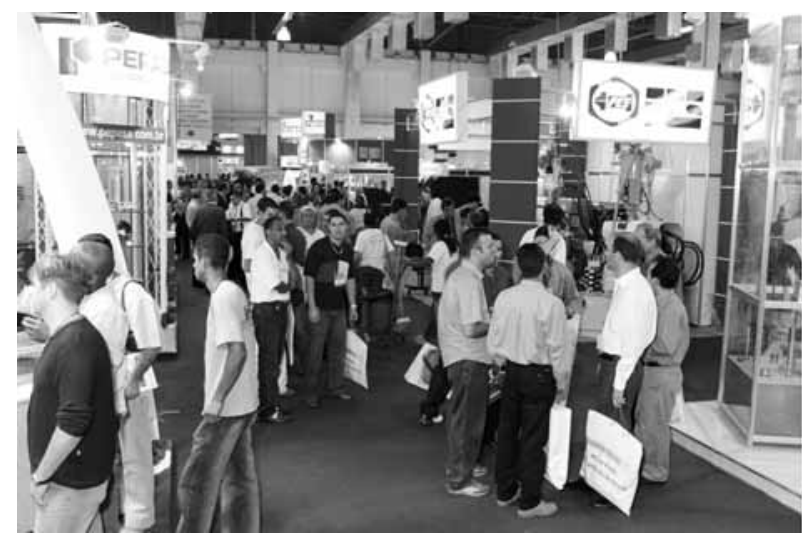

A feira ocupou um espaço de 3 mil metros quadrados no pavilhão verde do Expo Center Norte, recebendo cerca de 7.800 visitantes. Dentre os expositores, atuando em

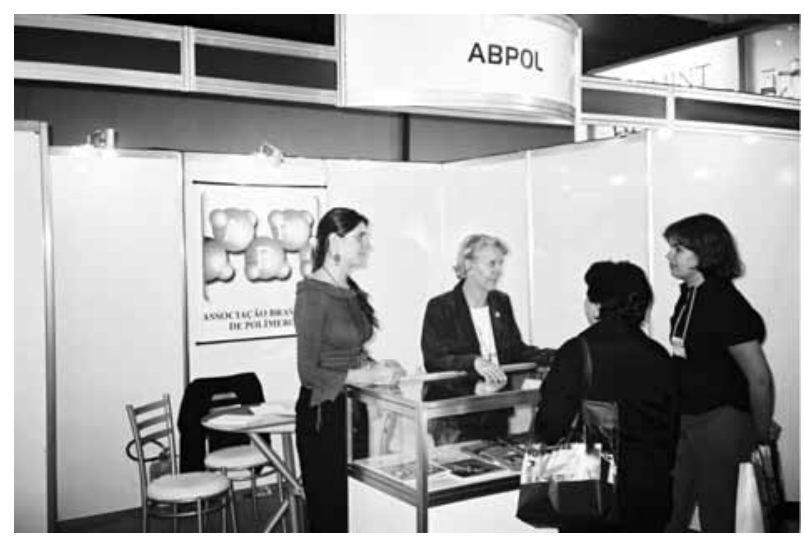

setores bastante diversificados, destacam-se as seguintes empresas: Ind. Romi, GE Plastics - LNP Mixcim, Uniflon, Refrisat, Piramidal, Celmar, Miotto, Activas, Implastec, Ruttino, Petropol, Smarttech, Plásticos Bom Pastor, Polimold, Ciba, 3M, Himaco, SKM, etc.

$\mathrm{O}$ perfil dos visitantes e congressistas, mostrou-se também bastante variado. $\mathrm{O}$ porte e categoria das máquinas expostas certamente foi de encontro às expectativas dos participantes, composto por $79 \%$ de transformadores, $14 \%$ usuários e $7 \%$ recicladores. Desse total, $63 \%$ produzem para terceiros e $37 \%$ para uso próprio.
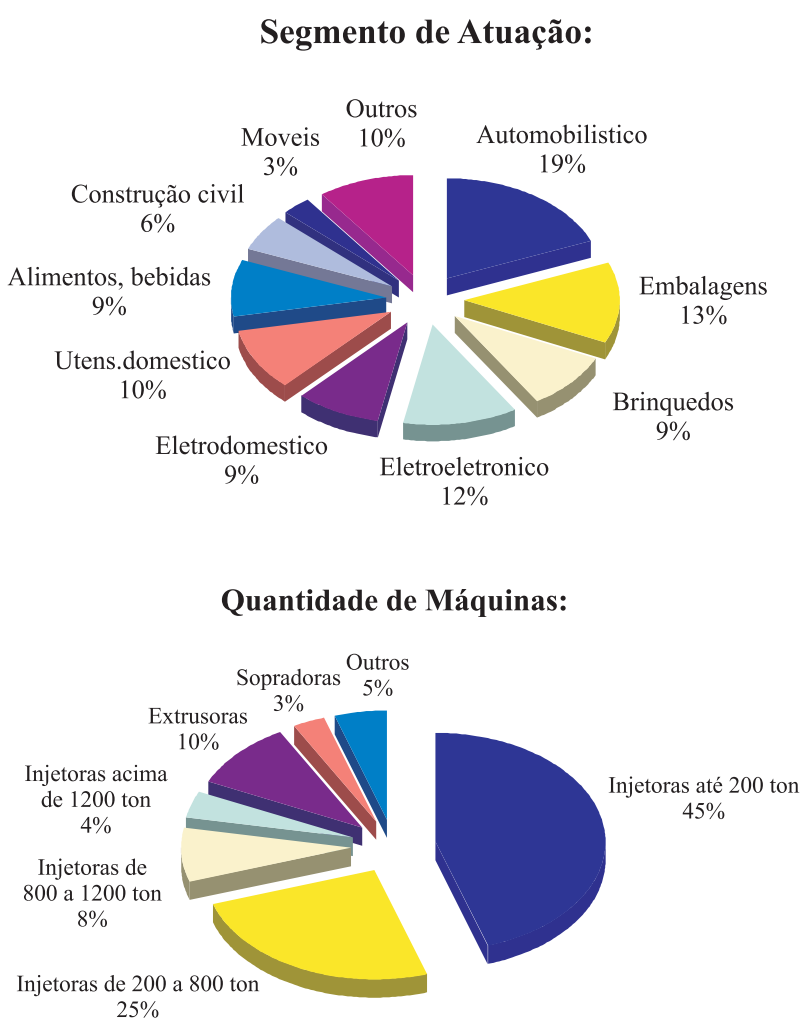

A ABPol, presente novamente no PlastShow com um stande gentilmente cedido pelos organizadores, através dos numerosos e profícuos contatos mantidos pôde comprovar o grande interesse do público tanto pelas apresentações técnicas quanto pela diversidade de produtos e serviços trazidos pelos expositores. A Aranda Eventos sem dúvida está preenchendo uma importante lacuna no mercado de exposições, conciliando a feira com um congresso altamente direcionado para um público ávido por informações técnico-mercadológicas. Ficam aqui externados os agradecimentos da Diretoria da ABPol pela oportunidade oferecida e os parabéns pelo sucesso da iniciativa. 